\title{
РОЗВИТОК В УКРАЇНI МЕХАНІЗМІВ ДЕРЖАВНОГО РЕГУЛЮВАННЯ СИСТЕМИ ПРОФЕСІЙНИХ КВАЛІФІКАЦІЙ
}

\author{
Семигіна Т. В., Баланюк Ю. В.
}

\section{ВСТУП}

Сучасний світ відрізняється динамічністю та інтенсивністю суспільних змін. Швидко виникають нечувані раніше професії та безперервно видозмінюються трудові функції тих професій, що існували споконвіку, стрімко поширюються модерні знання та виробляються нові навички, формується поліпрофесіоналізм, відбувається «старіння компетенцій» та утворюється дисбаланс освітньо-професійних кваліфікацій, налагоджуються гнучкі трудові відносини на ринку праці, а бізнес мусить перманентно розвиватись, аби залишатись конкурентоспроможним. На такі новітні тенденції звертають увагу вітчизняні ${ }^{1,2,3,4}$ та закордонні ${ }^{5,6}$ науковці.

Невпинна трансформація ринку праці та потреби розвитку людського капіталу висувають безпрецедентні вимоги до системи освіти. Адже навчання тепер, як зазначають європейські нормативні документи ${ }^{7}$, фактично триває впродовж усього життя людини й може

1 Ільїч Л. Старіння компетенцій та освітньо-кваліфікаційний дисбаланс як об'єктивна реальність сучасного ринку праці. New economics: матеріали Міжнар. наукового форуму “NEW ECONOMICS. 2019» (м. Київ, 14-15 листопада 2019 р.): в 2-х томах. T. 1. 2019. URL: http://www.aenu.org/download/monographs/Forum2019_ T1.pdf\#page $=179$ (дата звернення: 03.05.2020 p.).

2 Іорданов А. Механізми взаємодії державних, суспільних та ринкових інститутів в управління людським капіталом регіону. Інвестиції: практика та досвід. 2010. № 8. С. 94-96.

${ }^{3}$ Кваша О. Ринок праці в Україні: аналіз сучасного стану та перспективи розвитку. Вісник Миколаӥвського наџіонального університету імені В. О. Сухомлинського. 2018. Вип. 22. С. 1074-1079.

4. Науково-методичне забезпечення професійної освіти і навчання : збірник матеріалів XIV звітної Всеукраїнської науково-практичної конференції (м. Київ, 7 травня 2020 р.) / за заг. ред. В. О. Радкевич. Київ : ІПТО НАПН України, 2020. 431 с.

${ }^{5}$ Weil D. The Fissured Workplace: why work became so bad for so many and what can be done to improve it. Harvard : Harvard University Press, 2014. 424 p.

${ }^{6}$ Payne J. What do trade unions want from lifelong learning? Research in PostCompulsory Education. 2001. Vol. 6:3. P. 355-373.

7 The Council of the European Union 2017/C 189/03 Recommendation on the European Qualifications Framework for lifelong learning and repealing the 
мати як формальний, так і неформальний характер. Зважаючи на це, національна політика в багатьох країнах передбачає розробку та впровадження процедур визнання результатів будь-якого професійного навчання, зокрема й неформального ${ }^{8,9}$. Дедалі більше такі процедури мають стати невіддільним складником національної, а в деяких випадках - i міжнародної системи професійних кваліфікацій, що складається з відповідних правових норм та інституцій, яких відносять до суб'єктів політики.

Водночас регулювання системи професійних кваліфікацій виходить за межі державної політики освіти, адже тут відбувається взаємодія освіти, ринку праці та інтересів ширшого суспільства. Погоджуємось із думкою української дослідниці Л. Ільїч, що така взаємодія виступає як «технологія узгодження поведінки всіх суб'єктів ринкових відносин (держави, профспілок, організацій роботодавців, навчальних закладів, учнів та студентів), у процесі якої досягається узгодження попиту та пропозиції на кваліфіковану робочу силу, створюються передумови для відтворення людського капіталу та забезпечується стійке соціальноекономічне зростання» ${ }^{10}$. Водночас поділяємо думки О. Лазоренко та Р. Колишка щодо браку правового унормування відносини у сфері освіти дорослого населення ${ }^{11}$, а також Ю. Уварова та Т. Чікаліної, які звертають увагу на застарілість вітчизняних кваліфікаційних довідників і вимог ${ }^{12}$.

Ця стаття має на меті окреслити компоненти інтегральної системи професійних кваліфікацій як взаємодії між системою освіти, передовсім освіти дорослих, ринком та суспільством, а також визначити механізми регулювання такої системи в Україні в умовах

recommendation of the European Parliament and of the Council of 23 April 2008 on the establishment of the European Qualifications Framework for lifelong learning. URL: https://eur-lex.europa.eu/legal-content/EN/TXT/?uri=CELEX\%3A32017H0615(01) (дата звернення: 10.04 .2020 р.).

8 Лук'янова Л. Законодавче забезпечення освіти дорослих: зарубіжний досвід. Київ : ДКС-Центр, 2017. 147 с.

${ }^{9}$ Пуховська Л., Ворначев А., Мельник С., Кравець Ю. Професійні стандарти і кваліфікації у країнах з високорозвинутою економікою. Київ : НВП Поліграфсервіс, 2014. $176 \mathrm{c}$.

${ }^{10}$ Ільїч Л. Взаємодія ринків праці та освіти: сутність, характерні риси та модель функціонування. Економіка та держава. 2017. № 4. С. 71.

11 Лазоренко О., Колишко Р. Аналітичний звіт дослідження у сфері неформальної освіти дорослих у пілотних областях в Україні: Полтавська та Львівська область. Київ, 2010. С. 44.

${ }^{12}$ Уваров Ю., Чікаліна Т. Сучасні підходи до створення професійних стандартів у системі освіти. Вісник Науково-методичного центру навчальних закладів сфери циивільного захисту. 2017. № 26. С. 72-77. 
децентралізації. Дослідження базується на неоіституціональних підходах до аналізу державної політики.

\section{1. Компоненти національної системи професійних кваліфікацій}

Основи вітчизняної системи професійних кваліфікацій закладені в Законі України «Про освіту» ${ }^{13}$, ухваленому у 2017 році. За визначенням, наведеним у законодавстві, така система являє собою сукупність інституцій і правових норм, які регулюють процеси формування освітніх та/або професійних вимог до осіб, відповідно до потреб суспільства та ринку праці, оцінювання кваліфікаційного рівня.

Привертає увагу той факт, що кваліфікація розуміється як «визнана вповноваженим суб'єктом та засвідчена відповідним документом стандартизована сукупність здобутих особою компетентностей (результатів навчання)». Тобто компетентності (особистісні якості) фактично ставляться на один щабель із результатами навчання (ті особистісні якості, що були набуті внаслідок навчання та які піддаються вимірюванню).

Згідно зі ст. 34 Закону кваліфікації за обсягом класифікуються на повні та часткові, за змістом - на освітні та професійні. Кваліфікація вважається повною в разі здобуття особою повного переліку компетентностей відповідного рівня Національної рамки кваліфікацій, які визначені відповідним стандартом. Кваліфікація вважається частковою в разі здобуття особою частини компетентностей відповідного рівня Національної рамки кваліфікацій, що визначені відповідним стандартом.

«Освітня кваліфікація» - це визнана закладом освіти чи іншим уповноваженим суб'єктом освітньої діяльності та засвідчена відповідним документом про освіту сукупність установлених стандартом освіти та здобутих особою результатів навчання (компетентностей). А «професійна кваліфікація» - це визнана кваліфікаційним центром, суб'єктом освітньої діяльності, іншим уповноваженим суб'єктом та засвідчена відповідним документом стандартизована сукупність здобутих особою компетентностей (результатів навчання), котрі дозволяють виконувати певний вид роботи або здійснювати професійну діяльність. Установлено, що основою для формування професійних кваліфікацій є професійний стандарт - це затверджені в установленому порядку вимоги до компетентностей працівників.

Під час формулювання положень українського освітнього законодавства, яке видавалось досить прогресивним на момент його

13 Про освіту : Закон України № 2145-VIII від 5.09.2017 p. URL: https:// zakon.rada.gov.ua/laws/show/2145-19 (дата звернення: 08.04.2020 p.). 
ухвалення, були (якщо можна) враховані норми європейських конвенції та рекомендацій. Зокрема, замість освітньо-кваліфікаційних рівнів та ступенів було запроваджено рівні Національної рамки кваліфікацій. Також було передбачено запуск роботи кваліфікаційних центрів, тобто суб'єктів, уповноважених на оцінювання й визнання результатів навчання осіб (зокрема, здобутих шляхом неформальної чи інформальної освіти), присвоєння та/або підтвердження відповідних професійних кваліфікацій.

Необхідно зазначити, що європейські норми розвивались швидше, аніж в Україні змінювалось освітне законодавство. I в тому ж таки 2017 році ухвалено Рекомендацію Ради СС 2017/C 189/03 про Європейську рамку кваліфікацій для навчання впродовж усього життя та скасування рекомендації Європейського Парламенту та Ради від 23 квітня 2008 р. про створення європейської рамки кваліфікацій для навчання упродовж усього життя ${ }^{14}$. Цей документ зважає на модерні освітні тренди і спрямований на забезпечення підгрунтя для визнання результатів навчання дорослих, створення правового та інституційного поля підтвердження професійних кваліфікацій, здобутих шляхом неформального навчання.

Рекомендація Ради ЄС тлумачить кваліфікацію як формальний результат процесу оцінювання (водночас кваліфікація отримується, коли компетентний орган визначає, що людина досягла результатів навчання за певними стандартами). Як бачимо, тут не йдеться про компетентності або певні особистісні якості, а саме про вимірюваність наслідків опанування щось.

У документі зазначено, що для порівняння кваліфікацій, які встановлюються за результатами навчання, i, відповідно, для полегшення міжнародного визнання кваліфікацій варто орієнтуватись на Європейську рамку кваліфікацій для навчання впродовж життя (СРК). Нинішня ЄРК складається 3 восьми кваліфікаційних рівнів, котрі описуються через такі ключові дескриптори, як знання (knowledge), навички (skills), відповідальність (responsibility) та автономія (autonomy). Відповідно, держави повинні ухвалити національні рамки кваліфікацій (НРК), які не повинні дублювати СРК, але відповідати їй та адаптувати іiі відповідно до національного бачення.

14 The Council of the European Union 2017/C 189/03 Recommendation on the European Qualifications Framework for lifelong learning and repealing the recommendation of the European Parliament and of the Council of 23 April 2008 on the establishment of the European Qualifications Framework for lifelong learning. URL: https://eur-lex.europa.eu/legal-content/EN/TXT/?uri=CELEX\%3A32017H0615(01) (дата звернення: 10.04.2020р.). 
Нині більшість європейських країн (Великобританія, Німеччина, Данія, Нідерланди та інші) мають сформовані системи професійних кваліфікацій: упроваджено системи оцінювання та визнання кваліфікацій на основі професійних стандартів, котрі встановлюють єдині вимоги до компетентності працівників і співвідносні 3 рівнями професійної кваліфікації в межах визначеної галузі діяльності ${ }^{15}$. Водночас вагому роль відіграють професійні організації, які беруть на себе відповідальність із розроблення професійних стандартів, а головне - фаховий контроль за їхнім дотриманням. Такі професійні асоціації діють у більшості країн Європи, США, Канаді та інших країнах. Саме їм держава делегує повноваження щодо присвоєння професійних кваліфікацій на підставі професійних стандартів, розроблених самими асоціаціями. Таке делегування повноважень вважають виявом функціональної децентралізації та деконцентрації влади, коли відбувається передача повноважень щодо прийняття рішень і ресурсів значно ближче до цільової популяції, а не тільки на рівень місцевого самоврядування ${ }^{16}$.

Отже, сучасні національні системи кваліфікацій базуються на концепції результатів навчання та на механізмах перевірки результатів неформального навчання, котре може тривати впродовж усього життя, та там, де це доцільно, із системами навчальних кредитів. Для оцінки результатів навчання i присвоєння кваліфікацій застосовують професійні стандарти, розробниками яких виступають практики, тобто ті, хто керуватиметься стандартом у роботі. Формування та забезпечення ефективної діяльності цих елементів потребує належного застосування інструментів політики 3 високим рівнем примусу (за класифікацією інструментів політики, описаними Л. Палом ${ }^{17}$ або М. Говлетом та М. Рамешем ${ }^{18}$ ), тобто державного втручання та державного регулювання, унормування правил взаємодії між різнорівневими гравцями системи професійних кваліфікацій.

\section{2. Створення Національного агентства кваліфікацій як провідної інституції системи професійних кваліфікацій}

У багатьох європейських країнах ключовим суб'єктом системи професійних кваліфікацій виступають спеціальні урядові агентства

${ }^{15}$ Балашова Н., Літвінчук Л. Міжнародна практика стандартизації професій та кваліфікацій: досвід для України. Ринок праці та зайнятість населення. 2019. № 1-2. С. $62-69$.

${ }^{16}$ Семигіна Т. Децентралізація і політика охорони здоров'я. Гілея. 2014. Вип. 84. C. $461-465$.

${ }^{17}$ Пал Л. Аналіз державної політики. Київ : Основи, 1999. С. 205-210.

${ }^{18}$ Говлет М., Рамеш М. Дослідження державної політики: цикли та підсистеми політики. Львів : Кальварія, 2004. С. 93-113. 
(уповноважені інституції), які відповідають за питання присвоєння кваліфікацій та забезпечення якості навчання впродовж життя.

У Законі України «Про освіту» (вересень 2017 р. $)^{19}$ було передбачено формування Національного агентства кваліфікацій (далі в тексті - НАК), колегіального органу, уповноваженого на реалізацію державної політики у сфері кваліфікацій. Статут НАК затверджено через рік після ухвалення законодавства - у грудні 2018 p. ${ }^{20}$. За Статутом цей публічний колективний орган уповноважений на реалізацію державної політики у сфері кваліфікацій. Передбачено, що НАК бере участь у розробленні нормативно-правових актів у сфері кваліфікацій; забезпечує взаємодію, координацію та підвищення ефективності діяльності зацікавлених сторін у сфері кваліфікацій; супроводжує запровадження Національної рамки кваліфікацій, здійснює міжнародне співробітництво у сфері кваліфікацій, зокрема 3 метою гармонізації Національної рамки кваліфікацій із відповідними міжнародними документами; створює й веде Реєстр кваліфікацій; координує розроблення професійних стандартів, реєструє такі стандарти та забезпечує відкритий доступ до стандартів; здійснює акредитацію кваліфікаційних центрів; розробляє критерії та процедури визнання професійних кваліфікацій, здобутих в іноземних державах; формує вимоги до процедур присвоєння кваліфікацій, визнання результатів неформального та інформального навчання, вивчає потреби у професійних кваліфікаціях тощо.

Відповідно до пункту 13 Статуту НАК до складу агентства входить 12 членів, із яких по два представники - від Міністерства освіти й науки України, Міністерства соціальної політики України, Міністерства економічного розвитку й торгівлі України, по три - від Спільного представницького органу сторони роботодавців на національному рівні та Спільного представницького органу репрезентативних усеукраїнських об'єднань профспілок на національному рівні. По суті, НАК є одним 3 інститутів соціального діалогу (такі ж принципи соціального партнерства закладені в основу формування схожих інституцій у європейських країнах). Персональний склад НАК затверджено рішенням Кабінету Міністрів України у квітні 2019 року $^{21}$. Тривалість однієї каденції складу НАК - три роки.

19 Про освіту : Закон України № 2145-VIII від 5.09.2017 p. URL: https:// zakon.rada.gov.ua/laws/show/2145-19 (дата звернення: 08.04.2020р.).

20 Деякі питання Національного агентства кваліфікацій: Постанова Кабінету Міністрів України № 1029 від 5.12. 2018 p. URL: https://zakon.rada.gov.ua/laws/ show/1029-2018-п (дата звернення: 24.05.2020 p.).

${ }^{21}$ Про затвердження складу Національного агентства кваліфікацій : Розпорядження Кабінету Міністрів України розпорядженням від 03.04.2019 № 219-p. URL: https:// zakon.rada.gov.ua/laws/show/219-2019-\%D1\%80 (дата звернення: 24.05 .2020 p.). 
У листопаді 2019 року Агентство нарешті було зареєстровано як державну організацію в Сдиному державному реєстрі юридичних осіб, фізичних осіб-підприємців та громадських формувань. Для цього довелось чекати набрання чинності Закону України «Про внесення змін до Закону України «Про Державний бюджет України на 2019 рік» ${ }^{22}$, яким НАК надано фінансування.

У структурі Агентства задля організаційного, фінансово-господарського, матеріально-технічного, інформаційно-довідкового та іншого забезпечення його діяльності передбачено секретаріат Агентства. Секретаріат Агентства розпочав свою діяльність у листопаді 2019 року.

Ключовими напрямами першого етапу діяльності НАК стали:

1) налагодження комунікації та інституційних зв'язків із вітчизняними та закордонними стейкхолдерами системи професійних кваліфікацій;

2) формування правового та інституційного поля діяльності кваліфікаційних (екзаменаційних) центрів, де можна підтвердити професійну кваліфікацію;

3) ініціювання перегляду процедур розробки професійних стандартів;

4) робота над запуском національного реєстру кваліфікацій (відпрацювання модулів такого реєстру та підготовка нормативноправової бази для його функціонування);

5) опрацювання наявних підходів до прогнозування потреб ринку праці у кваліфікаціях та проведення аналітичної роботи з вивчення поточного попиту на професійні кваліфікації тощо;

6) розроблення нової редакції Класифікатора професій.

Так, Агентство підготувало проєкт Положення про порядок акредитації кваліфікаційних центрів ${ }^{23}$, яким визначено: критерії для акредитації кваліфікаційних центрів за професійною кваліфікацією чи групами кваліфікацій; процедури проведення акредитації; вимоги до експертів, котрі мають проводити акредитаційну експертизу; правовий статус експерта, порядок формування реєстру експертів; порядок фінансування послуг із проведення акредитації тощо.

${ }^{22}$ Про внесення змін до Закону України «Про Державний бюджет України на 2019 рік : Закон України від 31.10.2019 № 265-IX. URL: https://zakon.rada.gov.ua/ laws/show/265-20n (дата звернення: 18.05.2020 р.).

${ }^{23} \mathrm{MOH} \mathrm{пропонує} \mathrm{для} \mathrm{громадського} \mathrm{обговорення} \mathrm{проєкт} \mathrm{постанови} \mathrm{КМУ} \mathrm{«Про}$ затвердження Положення про акредитацію кваліфікаційних центрів» / Міністерство освіти і науки України. 2020. URL: https://mon.gov.ua/ua/news/mon-proponuye-dlyagromadskogo-obgovorennya-proyekt-postanovi-kmu-pro-zatverdzhennya-polozhennyapro-akreditaciyu-kvalifikacijnih-centriv?fbclid=IwAR3I7EbLp8NRJ-8sXYfYhHSiVGRa_ VylBHgQOSiQkYCCxQHzxUCRLBRnjwI (дата звернення: 22.05.2020 p.) 
За погодженням із Міністерством освіти й науки України НАК долучилось до роботи над проєктом Закону України «Про національну систему кваліфікацій» ${ }^{24}$. Метою цього законодавчого акта визначено правове врегулювання питань присвоєння професійних кваліфікацій, ключових аспектів взаємодії зацікавлених сторін у межах Національної системи кваліфікацій (необхідно додати, що це вже не перша спроба в Україні розробити та ухвалити спеціальне законодавство; один із попередніх варіантів було подано до Верховної Ради України ще у 2011 році ${ }^{25}$ ).

Також Агентство організувало цілу низку заходів у співпраці 3 різними партнерами, зокрема міжнародними, 3 різних питань, віднесених до сфери компетенції НАК, - діяльність кваліфікаційних центрів, розроблення професійних стандартів, формування Національної рамки кваліфікацій.

Доречно зауважити, що НАК, хоча й перебуває в безпосередньому підпорядкуванні Кабінету Міністрів України, не $\epsilon$ центральним органом виконавчої влади, а тому не має повноважень уносити проєкти нормативно-правових актів на громадське обговорення, подавати їх до Кабінету Міністрів України, тобто має обмежені можливості інституційного впливу на політику.

\section{3. Перспективні механізми державного регулювання системи професійних кваліфікацій в Україні}

Формування національної системи професійних кваліфікацій в Україні та реалізація передбачених законодавством функцій Національного агентства кваліфікацій відбувається не на порожньому місці.

Ще у 2013 році Кабінет Міністрів України ухвалив Порядок підтвердження результатів неформального професійного навчання осіб за робітничими професіями ${ }^{26}$. На виконання цього Порядку у 2016 році Міністерством соціальної політики України визначено центри, де

${ }^{24} \mathrm{MOH} \mathrm{пропонує} \mathrm{до} \mathrm{повторного} \mathrm{громадського} \mathrm{обговорення} \mathrm{проєкт} \mathrm{Закону}$ України «Про національну систему кваліфікацій» / Міністерство освіти і науки України. 2020. URL: https://mon.gov.ua/ua/news/mon-proponuye-do-gromadskogoobgovorennya (дата звернення: 22.05 .2020 р.)

25 Проєкт Закону про національну систему кваліфікацій, зареєстрований за 8726 від 30.06.2011. URL: http://w1.c1.rada.gov.ua/pls/zweb2/webproc4_2?pf3516= 8726\&skl=7(дата звернення: 22.05.2020 p.)

26 Про затвердження Порядку підтвердження результатів неформального професійного навчання осіб за робітничими професіями : Постанова Кабінету Міністрів України № 340 від 15.03.2013 p. URL: https://zakon.rada.gov.ua/ laws/show/340-2013-\%D0\%BF\#n16 (дата звернення: 18.03.2020р.). 
можна підтвердити результати неформального навчанняя ${ }^{27}$. Однак дія цих документів поширюється тільки на професію «кухар», діють лише три суб'єкти, де можна таку кваліфікацію підтвердити, із 2016 до 2019 року цією можливістю скористались близько 200 осіб $^{28}$.

У 2015 р. оновлено порядок визнання іноземних дипломів, зокрема документів про професійну освіту ${ }^{29}$. Однак наразі відсутня публічна інформація про те, скільки осіб звернулось за визнанням іноземних дипломів про закінчення закладів професійно-технічної освіти.

У 2017 році ухвалено Порядок розроблення та затвердження професійних стандартів ${ }^{30}$. Однак, по-перше, нормативний документ виявився не надто дієвим: за три роки в Україні з'явилось близько 25 стандартів. По-друге, розробка профстандартів жодним чином не прив'язана до Національної рамки кваліфікацій, затвердженої ще у 2011 p. $^{31}$.

В Україні діє Класифікатор професій ${ }^{32}$, тільки в межах якого можливе розроблення професійних стандартів, а тому й підтвердження професійних кваліфікацій. Проте він не відповідає сучасним європейським практикам визначення видів професійної діяльності.

Отже, хоча в Україні є певні нормативно-правові акти, покликані регулювати елементи системи професійних кваліфікацій, однак ці документи розроблені в інших реаліях і з іншою філософією, аніж визнання навчання упродовж життя, $\epsilon$ застарілими, надмірно бюрократичними як в адмініструванні, так і для тих, на кого воно спрямовані, для цільової групи, не узгоджені із загальноєвропейськими практиками.

27 Про затвердження Переліку суб'єктів підтвердження результатів неформального професійного навчання осіб за робітничими професіями: наказ Мінсоцполітики від 16.03.2016 року № 256. URL: https://zakon.rada.gov.ua/laws/ show/z0455-16\#n13 (дата звернення: 18.03.2020 p.).

28 Підтвердження неформального навчання. Державна служба зайнятості Украӥни. URL: https://www.dcz.gov.ua/storinka/pidtverdzhennya-neformalnogo-navchannya (дата звернення: 22.03.2020 р.).

29 Деякі питання визнання в Україні іноземних документів про освіту : Наказ Міністерства освіти та науки України від 05.05.2015 № 504. URL: https://zakon.rada.gov.ua/laws/show/z0614-15 (дата звернення: 18.03.2020 p.).

30 Про затвердження Порядку розроблення та затвердження професійних стандартів : Постанова Кабінету Міністрів України № 373 від 31.05.2017 p. URL: https://zakon.rada.gov.ua/laws/show/373-2017-\%D0\%BF (дата звернення: 18.03.2020р.).

31 Про затвердження Національної рамки кваліфікацій : Постанова Кабінету Міністрів України № 1341 від 23.11.2011 p. URL: https://zakon.rada.gov.ua/laws/show/ 1341-2011-\%D0\%BF (дата звернення: 18.03.2020 p.).

32 Національний класифікатор «Класифікатор професій ДК 003:2010» (затверджений наказом Держспоживстандарту України 28.07.2010 № 3217). URL: https://zakon.rada.gov.ua/rada/show/va327609-10 (дата звернення: 18.03.2020 p.). 
Водночас на момент започаткування роботи НАК у країні діяли кваліфікаційні (екзаменаційні) центри, котрі приймали іспити та видавали сертифікати про присудження кваліфікацій (наприклад, центри в «Укрзалізниці» та Академії ДТЕК), але ця діяльність не $є$ унормованою чинним законодавством.

Таким чином, в Україні на момент створення Національного агентства кваліфікацій - нового органу, уповноваженого реалізовувати політику у сфері кваліфікацій, була відсутня узгоджена, когерентна правова база щодо професійних кваліфікацій і регульованих професій, професійних стандартів, Національної рамки кваліфікацій, діяльності кваліфікаційних центрів і професійних асоціацій. Це висуває перед суб'єктами державної політики завдання сформувати такі інституційні механізми, які забезпечать осучаснення та гармонізацію державної політики щодо кваліфікацій ${ }^{33}$, призведуть до формування різнорівневої моделі, здатної забезпечити легітимацію процесів присудження та визнання професійних кваліфікацій за результатами формального та неформального навчання. Наше авторське бачення такої моделі схематично представлено на рис. 1. Запровадження моделі можливе через ухвалення відповідного спеціального закону про національну систему кваліфікацій.

Завдання, окреслені законодавством та Статутом НАК, виклики, що постали перед новою структурою, вивчення відповідного міжнародного досвіду дають підстави окреслити низку механізмів державного регулювання сфери професійних кваліфікацій (табл. 1), які, на нашу думку, доцільні в ситуації, котра склалась в Україні на перше півріччя 2020 року. Ці механізми, грунтовані на інструментах-ефекторах (засобах впливу на ситуацію) та інструментах-детекторах (засобах виявлення ситуації), виходять за межі компетенції НАК і стосуються національної системи кваліфікацій загалом.

Варто зауважити, що лише взаємоузгодження проблемноорієнтованого, нормативного, організаційного та ресурсного проєктування цих окремих механізмів може забезпечити формування цілісного механізму державного регулювання системи професійних кваліфікацій в Україні. Запровадження цього механізму необхідно здійснювати за інкрементальним, тобто покроковим, підходом 3 урахуванням результатів аналізу експертних оцінок та отриманих результатів реалізації певних концептуальних підходів. 3 огляду на це вагоме місце в діяльності має посідати інституціоналізований

${ }^{33}$ Семигіна Т. Європейська політика щодо визнання професійних кваліфікацій: уроки для України. Науковий часопис Національного педагогічного університету імені М.П. Драгоманова. Серія 22. Політичні науки. 2020. Вип. 28. С. 5-14. 
моніторинг змін, які постали внаслідок упровадження норм нових нормативно-правових актів. I лише на цій підставі можливе втілення раціонального довгострокового підходу до державної політики 3 формування відповідної національної стратегії розвитку національної системи професійних кваліфікацій.

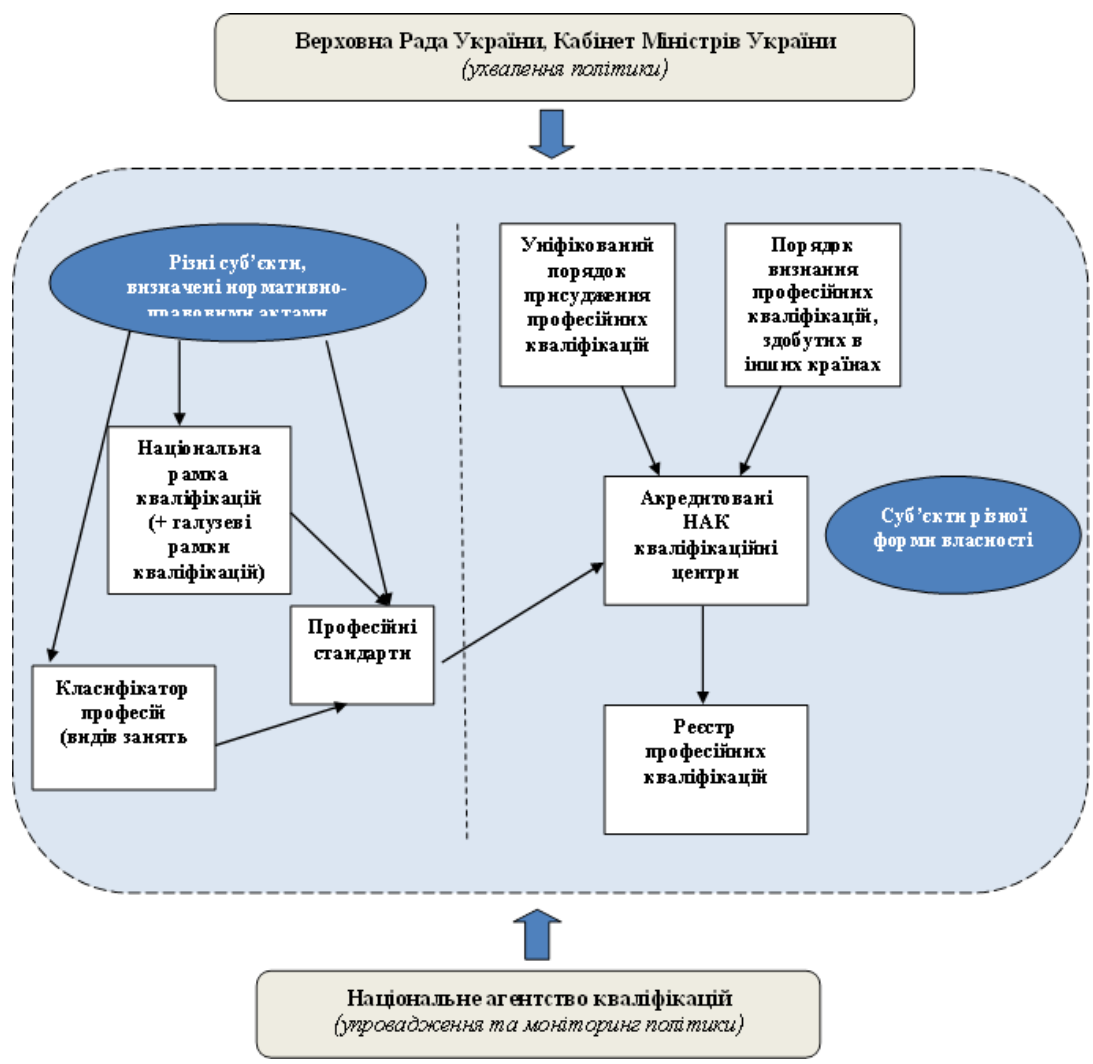

Рис. 1. Інституційна модель присудження та визнання професійних кваліфікацій за результатами формального та неформального навчання 


\section{Структура механізмів державного регулювання системи професійних кваліфікації}

\begin{tabular}{|c|c|c|}
\hline Тип механізму & Зміст & $\begin{array}{c}\text { Інструменти } \\
\text { (ефектори та детектори) }\end{array}$ \\
\hline 1 & 2 & 3 \\
\hline $\begin{array}{l}\text { Правовий } \\
\text { механізм }\end{array}$ & $\begin{array}{l}\text { Комплекс } \\
\text { взаємопов’язаних } \\
\text { правових актів } \\
\text { (юридичних засобів), які } \\
\text { визначають ключові } \\
\text { компоненти системи } \\
\text { професійних } \\
\text { кваліфікацій }\end{array}$ & $\begin{array}{l}\text { - Ухвалення Закону «Про } \\
\text { національну систему кваліфікацій» } \\
\text { (із новими принципами } \\
\text { функціонування системи). } \\
\text { - Перегляд законодавства щодо } \\
\text { чинної Національної рамки } \\
\text { кваліфікацій. } \\
\text { - Ухвалення Порядку акредитації } \\
\text { кваліфікаційних центрів. } \\
\text { - Унормування порядку присвоєння } \\
\text { та визнання професійних } \\
\text { кваліфікацій (зокрема, визнання } \\
\text { результатів неформального } \\
\text { навчання). } \\
\text { - Перегляд чинного порядку } \\
\text { розроблення та введення в дію } \\
\text { професійних стандартів. } \\
\text { - Перегляд чинного Класифікатора } \\
\text { професій. }\end{array}$ \\
\hline $\begin{array}{l}\text { Фінансовий } \\
\text { механізм }\end{array}$ & $\begin{array}{l}\text { Сукупність фінансових } \\
\text { форм, методів, важелів } \\
\text { та інструментів, за } \\
\text { допомогою яких } \\
\text { розподіляють і } \\
\text { використовують } \\
\text { фінансові ресурси. }\end{array}$ & $\begin{array}{l}\text { - Залучення фінансових ресурсів, } \\
\text { оптимізація витрат міжнародної } \\
\text { технічної допомоги. } \\
\text { - Фінансування розробки } \\
\text { професійних стандартів. } \\
\text { - Фінансування незалежних } \\
\text { кваліфікаційних центрів та центрів } \\
\text { на базі закладів професійно- } \\
\text { технічної освіти. } \\
\text { - Фінансування діяльності } \\
\text { Національного агентства } \\
\text { кваліфікацій. } \\
\text { - Ухвалення кошторисів (вартості) } \\
\text { послуг з акредитації кваліфікаційних } \\
\text { центрів, визнання кваліфікацій, } \\
\text { здобутих в інших країнах тощо. }\end{array}$ \\
\hline $\begin{array}{l}\text { Кадровий } \\
\text { механізм }\end{array}$ & $\begin{array}{l}\text { Система заходів і } \\
\text { стимулів, спрямованих } \\
\text { на розв'язання проблем } \\
\text { кадрового забезпечення } \\
\text { функціонування системи } \\
\text { професійних } \\
\text { кваліфікацій }\end{array}$ & $\begin{array}{l}\text { - Відбір та підготовка експертів } 3 \\
\text { акредитації кваліфікаційних центрів. } \\
\text { - Підготовка оцінювачів для роботи } \\
\text { у кваліфікаційних центрах. } \\
\text { - Залучення експертів для розробки } \\
\text { професійних стандартів та проєктів } \\
\text { нормативно-правових актів, котрі } \\
\text { стосуються професійних } \\
\text { кваліфікацій. }\end{array}$ \\
\hline
\end{tabular}


Закінчення табл. 1

\begin{tabular}{|c|c|c|}
\hline 1 & 2 & 3 \\
\hline $\begin{array}{l}\text { Інформаційно- } \\
\text { аналітичний } \\
\text { механізм }\end{array}$ & $\begin{array}{l}\text { Комплекс засобів і } \\
\text { методів інформаційно- } \\
\text { методичного та } \\
\text { аналітичного } \\
\text { забезпечення } \\
\text { функціонування й } \\
\text { розвитку системи } \\
\text { професійних } \\
\text { кваліфікацій. }\end{array}$ & $\begin{array}{l}\text { - Інформування суспільства та } \\
\text { стейкхолдерів щодо системи } \\
\text { професійних кваліфікацій та її } \\
\text { інновацій. } \\
\text { - Аналіз запитів ринку щодо } \\
\text { професійних кваліфікацій. } \\
\text { - Аналіз динаміки створення } \\
\text { кваліфікаційних центрів у різних } \\
\text { регіонах та галузях. } \\
\text { - Створення національного реєстру } \\
\text { кваліфікацій (розробка модулів бази } \\
\text { даних професійних кваліфікацій та } \\
\text { проєкту нормативно-правового } \\
\text { регулювання ведення цієї бази). } \\
- \text { Моніторинг упровадження змін у } \\
\text { системі професійних кваліфікацій. }\end{array}$ \\
\hline $\begin{array}{l}\text { Інституційний } \\
\text { механізм }\end{array}$ & $\begin{array}{l}\text { Сукупність } \\
\text { інституційних правил, } \\
\text { яка забезпечує } \\
\text { регулювальний вплив на } \\
\text { функціонування і } \\
\text { взаємодію суб'єктів } \\
\text { системи професійних } \\
\text { кваліфікацій. }\end{array}$ & $\begin{array}{l}\text { - Інституційний розвиток НАК. } \\
\text { - Розвиток та акредитація мережі } \\
\text { кваліфікаційних центрів, зокрема, на } \\
\text { базі закладів професійно-технічної } \\
\text { освіти. } \\
\text { - Проведення самосертифікації } \\
\text { НРК. } \\
\text { - Забезпечення зв'язку між НРК та } \\
\text { професійними стандартами. } \\
\text { - Сприяння розвитку галузевих рад } \\
\text { із професійних кваліфікацій та } \\
\text { саморегулівних професійних } \\
\text { утворень. } \\
\text { - Міжнародна співпраця з іншими } \\
\text { інституціями, відповідальними за } \\
\text { формування та впровадження } \\
\text { політики щодо професійних } \\
\text { кваліфікацій. }\end{array}$ \\
\hline
\end{tabular}

Джерело: складено авторами

\section{ВИСНОВКИ}

Проведене дослідження дає підстави для віднесення до компонентів національної системи професійних кваліфікацій таких елементів, як: Національна рамка кваліфікацій, галузеві рамки кваліфікацій, професійні стандарти, інституції, котрі формують політику у сфері професійних кваліфікацій та відповідають за ії впровадження; інституції, що відповідають за розроблення та контроль за дотриманням стандартів, інституції, які здійснюють валідацію професійних кваліфікацій, їх присвоєння та визнання кваліфікацій, здобутих в інших країнах, тощо. Усі ці елементи покликані забезпечити 
механізм визнання професійних кваліфікацій, котрі здобуваються людиною впродовж життя, і сприяти розвитку сучасних моделей освіти.

В Україні старт упровадження національного механізму державного регулювання системи професійних кваліфікацій дав Закон «Про освіту» (2017 р.). Саме на виконання цього законодавства у 2019 році було створено Національне агентство кваліфікацій як колегіальний орган, підпорядкований Кабінету Міністрів України, і водночас як один 3 інститутів соціального партнерства та діалогу.

Перший етап діяльності Національного агентства кваліфікацій виявив потребу в інкрементальному підході до зміни наявних в Україні правових норм та інституціоналізованих практик присвоєння професійних кваліфікацій та розроблення професійних стандартів. Водночас актуальним залишається формування цілісного механізму державного регулювання системи професійних кваліфікацій в Україні, який передбачатиме застосування різнопланових інструментів політики, спрямованих на унормування взаємодії між різнорівневими гравцями системи професійних кваліфікацій та підтримку нових інституційних практик присвоєння професійних кваліфікацій.

Перспективою подальших досліджень є обгрунтування основних положень Стратегії розвитку національної системи професійних кваліфікацій в Україні.

\section{АНОТАЦІЯ}

Трансформація освіти в сучасному світі вплинула на зміну процедур визнання результатів будь-якого професійного навчання, зокрема й неформального. Це зумовило формування відповідних національних політик щодо професійних та освітніх кваліфікацій.

Ця стаття має на меті окреслити компоненти інтегральної системи професійних кваліфікацій як взаємодії між системою освіти, передовсім освіти дорослих, ринком та суспільством, а також визначити механізми регулювання такої системи в Україні в умовах децентралізації. Дослідження проведене з урахуванням неоіституціональних підходів до аналізу державної політики.

На основі аналізу нормативно-правових актів та закордонного досвіду визначено такі ключові компоненти національної системи професійних кваліфікацій, як: Національна рамка кваліфікацій, галузеві рамки кваліфікацій, професійні стандарти, інституції, котрі формують політику у сфері професійних кваліфікацій та відповідають за іiі впровадження; інституції, що відповідають за розроблення та контроль за дотриманням стандартів, інституції, які здійснюють валідацію професійних кваліфікацій, їх присвоєння та визнання кваліфікацій, 
здобутих в інших країнах. Ці компоненти мають формувати інтегральну систему, котра відповідає потребам цільових груп та ринку.

В Україні почало діяти Національне агентство кваліфікацій, колегіальний орган, відповідальний за реалізацію політики щодо професійних кваліфікацій. Агентство створене на виконання Закону України «Про освіту». Водночас у країні діє ціла низка нормативноправових актів, які частково регулюють цю систему, однак $\epsilon$ застарілими та не відповідають динамічним змінам моделі професійної освіти.

Розвиток сучасної системи професійних кваліфікацій потребує застосування різнопланових механізмів державного регулювання, які беруть до уваги різнорівневий характер цієї системи та сучасні процеси деконцентрації влади.

\section{ЛІТЕРАТУРА}

1. Балашова Н., Літвінчук Л. Міжнародна практика стандартизації професій та кваліфікацій: досвід для України. Ринок праиі та зайнятість населення. 2019. № 1-2. С. 62-69.

2. Говлет М., Рамеш М. Дослідження державної політики: цикли та підсистеми політики. Львів : Кальварія, 2004. 264 с.

3. Деякі питання визнання в Україні іноземних документів про освіту : Наказ Міністерства освіти та науки України від 05.05.2015 № 504. URL: https://zakon.rada.gov.ua/laws/show/z0614-15 (дата звернення: 18.03.2020 p.).

4. Деякі питання Національного агентства кваліфікацій : Постанова Кабінету Міністрів України № 1029 від 5.12.2018 p. URL: https:// zakon.rada.gov.ua/laws/show/1029-2018-п (дата звернення: 24.05.2020р.).

5. Ільїч Л. М. Взаємодія ринків праці та освіти: сутність, характерні риси та модель функціонування. Економіка та держава. 2017. № 4. C. $69-74$.

6. Ільїч Л. М. Старіння компетенцій та освітньо-кваліфікаційний дисбаланс як об'єктивна реальність сучасного ринку праці. New есопотісs: матеріали Міжнар. наукового форуму "NEW ECONOMICS 2019» (м. Київ, 14-15 листопада 2019 р.): у 2-х томах. Т. 1. Київ, 2019. URL: http://www.aenu.org/download/monographs/Forum2019_T1.pdf\# page $=179$ (дата звернення: 03.05.2020 p.).

7. Іорданов А. Механізми взаємодії державних, суспільних та ринкових інститутів в управління людським капіталом регіону. Інвестииї: практика та досвід. 2010. № 8. С. 94-96. 
8. Кваша О. С. Ринок праці в Україні: аналіз сучасного стану та перспективи розвитку. Вісник Миколаївського національного університету імені В. О. Сухомлинського. 2018. Вип. 22. С. 1074-1079.

9. Лазоренко О. О., Колишко Р. А. Аналітичний звіт дослідження у сфері неформальної освіти дорослих у пілотних областях в Україні: Полтавська та Львівська область. Київ, 2010. 84 с.

10. Лук'янова Л. Законодавче забезпечення освіти дорослих: зарубіжний досвід. Київ : ДКС-Центр, 2017. 147 с.

11. МОН пропонує для громадського обговорення проєкт постанови КМУ «Про затвердження Положення про акредитацію кваліфікаційних центрів». Міністерство освіти $i$ науки України. 2020. URL: https://mon.gov.ua/ua/news/mon-proponuye-dlya-gromadskogoobgovorennya-proyekt-postanovi-kmu-pro-zatverdzhennya-polozhennyapro-akreditaciyu-kvalifikacijnih-centriv (дата звернення: 22.05 .2020 p.).

12. МОН пропонує до повторного громадського обговорення проєкт Закону України «Про національну систему кваліфікацій». Міністерство освіти і науки України. 2020. URL: https://mon.gov.ua/ua/ news/mon-proponuye-do-gromadskogo-obgovorennya (дата звернення: 22.05.2020 p.).

13. Науково-методичне забезпечення професійної освіти і навчання: збірник матеріалів XIV звітної Всеукраїнської науково-практичної конференції (м. Київ, 7 травня 2020 р.) / за заг. ред. В. О. Радкевич. Київ : ІПТО НАПН України, 2020. 431 с.

14. Національний класифікатор «Класифікатор професій ДК 003:2010» (затверджений наказом Держспоживстандарту України 28.07.2010 № 3217). URL: https://zakon.rada.gov.ua/rada/show/va32760910 (дата звернення: 18.03 .2020 р.).

15. Пал Л. Аналіз державної політики. Київ : Основи, 1999. 422 с.

16. Підтвердження неформального навчання. Державна служба зайнятості Украӥни. URL: https://www.dcz.gov.ua/storinka/pidtverdzhennya-neformalnogo-navchannya (дата звернення: 22.03 .2020 p.).

17. Про внесення змін до Закону України «Про Державний бюджет України на 2019 рік: Закон України від 31.10.2019 № 265-IX. URL: https://zakon.rada.gov.ua/laws/show/265-20n (дата звернення: 18.05 .2020 p.).

18. Проєкт Закону про національну систему кваліфікацій, зареєстрований за № 8726 від 30.06.2011. URL: http://w1.c1.rada.gov.ua/pls/ zweb2/webproc4_2?pf3516=8726\&skl=7(дата звернення: 22.05 .2020 p.).

19. Про затвердження Національної рамки кваліфікацій : Постанова Кабінету Міністрів України № 1341 від 23.11.2011 p. URL: https://zakon.rada.gov.ua/laws/show/1341-2011-\%D0\%BF (дата звернення: 18.03.2020 p.). 
20. Про затвердження Переліку суб'єктів підтвердження результатів неформального професійного навчання осіб за робітничими професіями : Наказ Мінсоцполітики від 16.03.2016 року № 256. URL: https://zakon.rada.gov.ua/laws/show/z0455-16\#n13 (дата звернення: 18.03.2020 p.).

21. Про затвердження Порядку підтвердження результатів неформального професійного навчання осіб за робітничими професіями : Постанова Кабінету Міністрів України № 340 від 15.03.2013 p. URL: https://zakon.rada.gov.ua/laws/show/340-2013$\% \mathrm{D} 0 \% \mathrm{BF} \# \mathrm{n} 16$ (дата звернення: 18.03.2020р.).

22. Про затвердження Порядку розроблення та затвердження професійних стандартів : Постанова Кабінету Міністрів України № 373 від 31.05.2017 p. URL: https://zakon.rada.gov.ua/laws/show/373-2017$\% \mathrm{D} 0 \% \mathrm{BF}$ (дата звернення: 18.03.2020 р.).

23. Про затвердження складу Національного агентства кваліфікацій : Розпорядження Кабінету Міністрів України розпорядженням від 03.04.2019 № 219-p. URL: https://zakon.rada.gov.ua/laws/show/219-2019$\% \mathrm{D} 1 \% 80$ (дата звернення: 24.05.2020р.).

24. Про освіту : Закон України № 2145-VIII від 5.09.2017 p. URL: https://zakon.rada.gov.ua/laws/show/2145-19 (дата звернення: 08.04.2020 p.).

25. Пуховська Л. П., Ворначев А. О., Мельник С. В., Кравець Ю. І. Професійні стандарти і кваліфікації у країнах з високорозвинутою економікою. Київ : НВП Поліграфсервіс, 2014. 176 с.

26. Семигіна Т. Європейська політика щодо визнання професійних кваліфікацій: уроки для України. Науковий часопис Національного педагогічного університету імені М. П. Драгоманова. Серія 22. Політичні науки. 2020. Вип. 28. С. 5-14.

27. Семигіна Т. В. Децентралізація і політика охорони здоров'я. Гілея. 2014. Вип. 84. С. 461-465.

28. Уваров Ю. В., Чікаліна Т. М. Сучасні підходи до створення професійних стандартів у системі освіти. Вісник Науково-методичного центру навчальних закладів сфери ичивільного захисту. 2017. № 26. C. $72-77$.

29. Payne J. What do trade unions want from lifelong learning? Research in Post-Compulsory Education. 2001. Vol. 6:3. P. 355-373.

30. The Council of the European Union 2017/C 189/03 Recommendation on the European Qualifications Framework for lifelong learning and repealing the recommendation of the European Parliament and of the Council of 23 April 2008 on the establishment of the European Qualifications Framework for lifelong learning. URL: https:// eur-lex.europa.eu/legal-content/EN/TXT/?uri=CELEX\%3A32017H0615(01) (дата звернення: 10.04.2020 р.). 
31. Weil D. The Fissured Workplace: why work became so bad for so many and what can be done to improve it. Harvard : Harvard University Press, 2014. 424 p.

\section{Information about authors: Semigina T. V.,} Doctor in Political Sciences, Professor, Member of National Qualification Agency 1, Solomianska Str., Kyiv, 03035, Ukraine

Balanyuk Yu. V., $\mathrm{PhD}$ in Technical Sciences, Chair of National Qualification Agency 1, Solomianska Str., Kyiv, 03035, Ukraine 